\title{
Somalia's Foreign Policy: Stages and Initial Odds
}

\author{
Abdalgani Aid Almi \\ Department of Global Studies and International Relations, New Generation University, Hargeisa \\ Email: qanoeid@gmail.com
}

How to cite this paper: Almi, A.A. (2021). Somalia's Foreign Policy: Stages and Initial Odds. Open Journal of Political Science, 11 , 370-377.

https://doi.org/10.4236/ojps.2021.113025

Received: January 9, 2021

Accepted: May 24, 2021

Published: May 27, 2021

Copyright () 2021 by author(s) and Scientific Research Publishing Inc. This work is licensed under the Creative Commons Attribution International License (CC BY 4.0)

http://creativecommons.org/licenses/by/4.0/

\begin{abstract}
Somalia is a state not like the other states in Africa, it's a state that came into existence after the unification of British Somaliland and Italian Somalia. It was considered to be one of the most democratic and civilized country in the region. But the administration of that time took a very naïve initiative to manage the circumstances. Due to the cold war and Ethiopia's antagonistic design against the newly established state of the Somali Republic, Somalia was compelled to develop close relations with the USSR. The roles, stages and initial odds of Somalia's foreign policy are discussed in this paper, with the use of primary and secondary sources of information. In conclusion, Somalia has limited options for its foreign policy, because of its financial position. Thus, the sovereignty of the country was compromised many times.
\end{abstract}

\section{Keywords}

Somalia, Foreign Policy, Interest, Alliance

\section{Introduction}

Foreign policy is the main determinant on how international system works, it is defined clearly. That it is concerned with the behavior of a state towards other states (Bojang, 2018). It is also one of the most important aspects of national policy components. The general objectives shape the performance and links of a state in its communication with other states. Moreover, while developing a foreign policy, there are many factors that influence it, such as; local deliberation, behavior of other countries, or strategies to develop certain geopolitical strategies (Encyclopædia Britannica, 2020).

Foreign policy leads a state to discover its potentials, in terms of national concerns and secure respected place among nations. So, it would be worthy to note that foreign policy will exist as long as the independent state practices in 
International level (Modelski, 1962).

What governments carry out for the purpose of managing their relationships with others nations of the world is called foreign policy (courses.lumenlearning, 2020). There are many objectives of any foreign policy. In illustration, the U.S foreign policy has these objectives: 1) protection of its citizens, 2) maintenance of access to national markets and resources, 3) sustaining of balance of power and 4) protection of human rights and democracy. China has so long followed the ti-yong dilemma, which is to combine going forward with looking backward-and to link theory with practice (Kim, 1994).

Going through the literature, one will find that foreign policy is an equipment used with a different measure, in illustration, China uses its foreign policy as a goal of achieving resource security. Moreover, it might be utilized as a device to stoke up public fervour.

Interest is the fueling idea of foreign policy. The foreign policy is merely the state's strategic interests to protect and safeguard its national agendas and achieve its goals within its international relation's ambience. National interest is the amalgamation of different state needed steps, which emerges during diplomatic meetings, bilateral and multilateral agreements. National interest is the foreign policy goals, objectives and policy preferences that supposedly benefit a nation as a whole. Moreover, foreign policy is equivalent of the 'public interest' (Heywood, 1997).

Foreign policy is not formulated in isolation; it is rather a dynamic process that seeks to reach the nation's internal needs and external influences. Moreover, in foreign policy there are no permanent friends or enemies among nations, but interests (thenews, 2020).

\section{Somalia's Foreign Policy and Somaliland's Factor}

Since Somaliland reclaimed its independence from the rest of Somalia, its foreign policy agenda and main national interest was to gain international recognition. As declared on Montevideo Convention, any state must have four basic pillars to be accepted by the international bodies, which are; 1) Permanent population, 2) Defined Territory 3) Functioning government and 4) capacity to enter into relations with the other states, Somaliland have maintained all these four prerequisites, yet recognition is not granted to it and not foreseen. Egal's foreign policy doctrine was "The best foreign policy is a good internal policy" (Duale \& Ahmed, 2018).

Somalia's stubborn antagonism to the Somaliland creation is based on two main claims, which are: 1) Somaliland declaration came at a time that the rest of Somalia was going through its hardest due to civil wars, 2) Birth of Somaliland is one step backward to the attainment of greater Somalia (Soomaali-Wayn). Somaliland developed a fear opposite to Somalia. This feeling of fear compelled the elite and policy makers in Somaliland to align and cooperate with Ethiopia, to gain a regional and continental support for its claim. 
Somalia suspends its relations with any state that creates any relation with Somaliland without its consensus. In illustration, Somalia announced the severing of diplomatic ties with West African country Guine Conakry (africanews, 2019). However, Somalia couldn't avoid to suspend its relations with the United Arab Emirates, or Ethiopia who undermined the Somalia's sovereignty by directly signing agreements with Somaliland without its Consensus.

\section{Somalia's Foreign Policy Objectives and Determinants}

The objective, is essentially an "Image" of a future state of affairs, it might be a goal set by some to achieve in the near future, determinant is a factor which decisively effects the nature or the outcome of a something (Oxford, 2020). The foreign policy objective of any state is to obtain its national interest, while foreign policy determinent is any factor that helps in shaping or moulding the foreign policy of any nation (Bojang, 2018). The national interest can indicate the ideal objectives which states pursue through their foreign policy (Seabury, 1963). Somalia's foreign policy is guided by two factors, which are; stability and security of its own environment (MFA, 2015). According to Sharmarke (Somalie's former prime minister), (Foreign Policy of Somalia, 2015), the main Objectives of Somalian foreign policy are; Peace and unification, through foreign policy. Somalia seeks to promote and safeguard its national, regional and international peace, and to protect its sovereign. Moreover, United Sates' foreign policy in Somalia is to promote economic and political stability, prevent Somalia to be a safe haven for international terrorism, eliminate hunger and humanitarian crises caused by decades of conflict, flooding and poor governance (State, 2018).

However, the prolonged conflict in Somalia, has shaped its foreign policy. Since Somaliland declared its independence on 18 May 1991, its main foreign policy objective was to attain recognition (Duale \& Ahmed, 2018). The Somalia's foreign policy objective is also greatly influenced by the lobbying against Somaliland's efforts.

Objectives and determinants of Somalia's foreign policy are discussed below:-

\subsection{National Security}

The main aim and objective of Somalia's foreign policy is its national security and sovereignty. Due to the conflict prone region that Somalia is part of, its national security is mainly considered, creating external relations with neighboring states. The primary foreign policy objective of Somalia is to maintain and protect its nation's values and interests. Furthermore, these interests include unity, peace and profitability through the world (MFA, 2015).

As stated by the Foreign Minister of Somalia

"The federal Republic of Somalia pursues its foreign policy within the Aftican integration process, in cooperation with its neighbors in East Africa, and as a member of the Intergovernmental Authority on Development (IGAD)."

However, Somalia's relations with neighboring states have been poisoned for 
decades because of its irredentist/irrefutable claim over areas inhabited by Somali ethnics in all of its bordering countries except Yemen.

\subsection{Financial Factor}

From the creation of the Somali Republic in July 1961, up to the current time, Somalia was financially weak, sometimes it was stronger than today; but, overtly depended on aid and loans. Just a few months after the independence Nasser of Egypt had lent Somalia a loan of Five million pounds, payable within seven years (Yehia, 2016). The debt Somalia owes to the external world creditors is estimated to be more than $\$ 5$ billion. USA is the biggest single lender, $\$ 1$ billion (Maruf, 2020).

However, the debt-trap (a situation where one country willfully extends excessive credit to another debtor country with the alleged intention of extracting economic or political concessions from the debtor country when it fails to honor its debt obligations) puts any country in a situation, that it cannot act freely within the international level. Thus, every country is compelled to be debt free to exercise its foreign policy independently.

\subsection{Ideological Factor}

Somalia is ideological state; its foreign policy is based on the ideology of greater Somalia (Soomaliwayn). This ideology was formed during the colonialism; its aim was to unify the five different regions of Somalis, which were: British Somaliland, Italian Somalia, French Somaliland, Ogaden/Reserve area and National Frontier District. This ideology was the main force behind the foundation of the Somali Republic in the 1960s. Moreover, the 1977-78 Ogaden war was the signaling demise of Pan-Somali Solidarity (Lewis, 1989).

However, Pan-Somali ideology has shaped Somali Foreign Policy so long. Claim of a "Great Somali" which aimed to incorporate ethnic Somali populations in Ethiopia, Kenya and Djibouti into the Somali Republic has deteriorated the neighborhood relations before it begun (Research Directorate, 1990).

\subsection{Good Relations with Neighbors}

In general, most of the African Countries having border issues and inter-state conflicts are more common. Despite the fact that Somalia had territorial disputes with its neighbors, it claimed territories that are internationally recognized as part of Ethiopia, Kenya or Djibouti. Yet, Somali wishes to be an equal partner with its neighbors, and seeks to be a catalyst for regional cooperation (Promotion, 2015). Decades of conflict and civil wars in the country undermined the Somali's ability to have equal, constructive relations with its neighbors; this ability will be improved with the improvement of peace and stability in the country.

\subsection{Establishment of Peace}

From the day of independence, Somalia was a dedicated state for peace and ad- 
vocate of conflict resolution by peaceful means. It supported the oppressed and colonized nations to get their freedom in a more civilized way. Furthermore, Somalia witnessed a prolonged civil wars, chaos and lawlessness for the last three decades. Thus, Somali's own security, stability and economic wellbeing depend on the stability of the sub-region, Africa, the Arab world and the rest of the world (Promotion, 2015).

Somalia emphasizes the Establishment of conflict resolution and prevention mechanisms and analysis capacity, nationally and regionally to maintain the progressive peace. According to report (Promotion, 2015), on international affairs as the most important condition for peace and development, Somalia expresses goodwill to all countries of the world and the support of human rights, has close brotherly relations and friendship with Muslim nations and the desire to cooperate with all countries for peace, specifically with neighboring countries.

\subsection{Cooperation with the UNO and AU}

Collaboration with the United Nations Organization is most vital for Somalia, as Somalia was lawless and a state without government for a long time, UNO have filled that vacuum and set up different special offices-such as; SRSG (Special Representative for Secretary Genera), UNOSOM (United Nations Office in Somalia) - for the restoration of hope and governance in Somalia. United Nations charter will be promoted by Somalia, as it will play its rightful role in supporting the work of the UN system in the promotion of international peace and security, trade, human rights, democracy, refugee protection, sustainable development and the reform of the UN system (Promotion, 2015).

Somalia's role in strengthening of the African Union and its institutions in accordance with the AU 2063 agenda, will advocate for the provisions of the AU constitutive act and the realization of its strategic objectives (Promotion, 2015).

\subsection{Independent and Neutral Policy}

From the independence and unification of the Somali Republic, Somalia adopted and followed the desire of independence, although the principle of non-alignment as a friend to all was not followed due to several reasons. Which are; 1) Somalia claimed the ownership of some territories, such as; Ogaden and reserve area of Ethiopia, NFD of Kenya, and the entire country of Djibouti, and 2) Somalia was not financially strong. Cold war was hindering every country not to be independent and neutral, specifically, ill governed and weak states have no other option except to align one of the two blocs, led by the USSR and USA.

From the very first, Somalia aligned with the Arabian countries. In illustration, Egypt can be mentioned, It has favored for Somalis from the colonial era as it also supported the Somalis in Ethiopia, Kenya and, Djibouti by promoting the ideology of Somali separatists within those regions. Later on Egypt was among the first to support Somalia militarily and financially (Yehia, 2016). A long struggle for liberation from colonialism, military dictatorship and civil conflict has 
shaped the independence of Somalia's foreign policy. However, during the Gulf crisis, Somalia played neutral role, even though Somalia's neutrality was important for Qatar (Sheikh, 2020).

\subsection{Ministry of Foreign Affairs}

Ministerial level can play a vital role regarding the formulation process of the foreign policies of any country; it is the collaboration of experts and specialists of foreign policy rules and regulations. The ministry is headed by the minister of foreign affairs, who cooperates with the prime minister regarding the matters related to foreign policy (Muzaffar, Yaseen, \& Ishfaq, 2016). Many times the prime minister plays a crucial part in determining the course of foreign affairs ministry (Bojang, 2018). Moreover, on the website of the ministry of foreign affairs, it is stated "Somalia is friend to all, enemy to none" (MFA, 2020).

\subsection{Intelligence Agencies}

Somalia's intelligence service has played a great role in the formulation of the country's foreign policy. Diplomats themselves were part of the Somali National Intelligence, to gather information regarding a targeted country to guide the kind of interest as well as the relations Somalia may have with that counterpart (Ducaale, 2016). However, after the demise of dictatorial regime of Siyad Barre in $1990^{\text {th }}$, intelligence never had any interference with diplomacy or foreign affairs' ministry.

\subsection{Interest Groups and Political Parties}

Political parties are very important in today's governance and democracy. According to Bojang (2018), political parties are vital to modern political settings, as they play an important role in shaping representative democracy in a country. Furthermore, interest groups influence the foreign policy (Sampson, 1962). Both political parties and interest groups play a great role in developing public opinion by expressing the will of the people (Haq, 1995). However, a special interest's lobbying activity may go up or down by the time, depending on how much attention the federal government takes on issues.

In Somalia, pressure groups are numberless, some are powerful than others and go beyond their limit by intervening the country's internal affairs and undermining its sovereignty. In illustration, the European union stated this-The European Union will review carefully how these events have come to pass, who bears responsibility and to what extent they deviate Somalia from the progress it was making-regarding the No-Confidence vote against Prime minister Khaire (Borrell, 2020).

\subsection{Role of Parliament}

Different political structures of a democratic system have an impact on foreign policies of a country. For instance, under a parliamentary system of government 
based on collaboration between the executive and legislative body, the close relations between these two wings have an impact on country's foreign policy (Bojang, 2018).

However, statements and press releases made by President, Prime Minister, or Foreign Minister, about the external affairs are debated by the parliaments, to support or even criticize it (Sampson, 1962). The sub-committee on foreign affairs and standing committee on foreign affairs are both well-functioning and responsible for foreign affair's monitoring and evaluation. Moreover, there is no clear constituent that defines the role of every diplomat in the Somali embassy; it can be indicated as a negligence of the parliament.

\section{Conclusion}

Somalia is a very well-known country internationally, from its independence; it promoted democracy, peace, and even went beyond and became an active state for Pan-Africanism. The friendly relations of Somalia and its territorial disputes with the neighboring countries have deteriorated its foreign policy, from the very first of its independence. Moreover, due to Ethiopia's antagonistic design against the newly established state of the Somali Republic, it compelled developing close relations with the USSR. Thus, the amalgamation of other factors, has brought up a dictatorial regime to overthrow democratically elected government, after then, the country's foreign policy has lost its navigation and just followed the communist block until the USSR aligned with Ethiopia during the 1977 Ethio-Somali war. However, this research study reveals, despite the complete surrender of Somalia's early leadership toward the USSR, the state couldn't get as much as they had expected.

In addition, there is much need for the country to revisit and redefine its foreign policy in a way that enhances the image of the country internationally and regionally. Country's foreign policy makers need to formulate policies that are free from external interventions. Furthermore, in today's world, the relations that states have with each other are merely a kind of economic interests and financial transactions. Somalia's foreign policy makers should reorient the relations with other states accordingly.

\section{Conflicts of Interest}

The author declares no conflicts of interest regarding the publication of this paper.

\section{References}

africanews (2019).

https://www.africanews.com/2019/07/04/somalia-cuts-diplomatic-ties-with-guinea-ove r-somaliland//

Bojang, A. S. (2018). The Study of Foreign Policy in International Relations. Journal of Political Science and Public Affairs, 6, Article ID: 1000337.

Borrell, J. (2020). Somalia: Statement by the High Representative/Vice-President Josep 
Borrell on the Recent Developments in the House of People. Brussels: European Union. courses.lumenlearning (2020).

https://courses.lumenlearning.com/amgovernment/chapter/defining-foreign-policy/

Duale, M. A., \& Ahmed, S. M. (2018).

https://somalilibrary.net/2019/04/13/somalilands-foreign-policy-analysis-the-first-four -administrations-in-perspective/

Ducaale, C. (2016). Raad-Raac: Taariikh Soomaaliyeed. Hargeisa: Sagaljet.

Encyclopædia Britannica (2020).

https://www.britannica.com/topic/foreign-policy

Foreign Policy of Somalia (2015). Mogadishou: Ministry of Foreign Affairs and Investment Promotion, The Federal Republic of Somalia.

Haq, M. (1995). Theory of Political Science. Lahore: Bookland Publications.

Heywood, A. (1997). Politics (4th ed.). London: Palgrave Macmillan. https://doi.org/10.1007/978-1-349-25543-6

Kim, S. S. (1994). China and the World. Boulder, CO: Westview Press.

Lewis, I. M. (1989). The Ogaden and the Fragility of Somali Segmentary Nationalism. African Affairs, 88, 573-579. https://doi.org/10.1093/oxfordjournals.afraf.a098217

Maruf, H. (2020). VOA.

https://www.voanews.com/africa/somalia-eligible-debt-relief

MFA (2015). https://www.mfa.gov.so/library/publications/

MFA (2020). http://www.mfa.gov.so

Modelski, G. (1962). A Theory of Foreign Policy. London: Princeton University.

Muzaffar, M., Yaseen, Z., \& Ishfaq, U. (2016). Pakistan's Foreign Policy: Initial Perspectives and Stages. Global Regional Review (GRR), 1, 61-74.

https://doi.org/10.31703/grr.2016(I-I).05

Oxford (2020).

https://www.oxfordlearnersdictionaries.com/definition/american english/objective 1

Promotion, M. O. (2015). Foreign Policy of Somalia. Mogadishu: Somali Federal Government.

Research Directorate, Immigration and Refugee Board, Canada (1990). Somalia/Ethiopia: Information about the WSLF and relations between Ethiopia and Somalia. Canada: Immigration and Refugee Board of Canada.

https://www.refworld.org/docid/3ae6ad8d3c.html

Sampson, A. (1962). Anatomy of Britain. New York: Anatomy of Britain.

Seabury, P. (1963). Power, Freedom, and Diplomacy: The Foreign Policy of the United States of America. New York: Vintage Books.

Sheikh, A. (2020).

https://af.reuters.com/article/topNews/idAFKCN1C81OC-OZATP

State (2018). https://www.state.gov/u-s-relations-with-somalia/

thenews (2020).

https://www.thenews.com.pk/latest/521621-in-foreign-policy-there-are-no-permanentfriends-or-enemies-fm-qureshi

Yehia, E. F. (2016). Why Somalis Cried at President Nasser's Death. African Journal of History and Culture, 8, 15-25. 